Ks dr Józef Młyński

Uniwersytet Kardynała Stefana Wyszyńskiego w Warszawie

Ks. dr Władysław Szewczyk

Wydział Teologiczny Sekcja w Tarnowie

\title{
Mistrz i uczeń - "Wszerz czy w głąb". Wywiad z ks. prof. Jerzym Bajdą
}

Rozmowa została nagrana 27 listopada 2012, na 12 dni przed śmiercią, za zgodą Rozmówcy. Miałem taką odwagę i potrzebę serca, ponieważ przez ponad 20 lat (1991-2012) pracowaliśmy obaj naukowo na ATK (UKSW) w Warszawie, w Instytucie Studiów nad Rodziną w Łomiankach (obecnie Wydział Studiów nad Rodziną Uniwersytetu Kardynała Stefana Wyszyńskiego w Warszawie).

Księże Profesorze, ma Ksiądz za soba sporo życia $i$ wiele rozmaitych doświadczeń, między innymi pracę $w$ seminarium tarnowskim $i$ wspótprace $z$ ks. kard. Karolem Wojtyła $w$ Krakowie oraz wiele lat pracy na wyższych uczelniach - Akademii Teologii Katolickiej i Uniwersytecie Kardynała Stefana Wyszyńskiego $w$ Warszawie. Co Ksiadz Profesor chciałby opowiedzieć o tych swoich doświadcze niach? Co, patrząc z perspektywy czasu, było dla Księdza jako naukowca i człowieka, a także kapłana najważniejsze?

Ks. prof. Jerzy Bajda: To dobrze, żeś to tak połączył - naukowca, człowieka, kapłana, zmieniłbym tylko kolejność: człowieka, kapłana, naukowca. Jakoś, 
tak bez specjalnego mojego starania, było to we mnie zawsze razem. Jakoś samo mi się to łączyło. Zawsze mnie nurtowało takie przekonanie że człowiek jest tak przez Boga pomyślany, że ma wielką godność, że jest dla siebie i dla innych wielką tajemnicą. Żeby tylko człowiek potrafił rozpoznać tę godność, no i związane z tym wezwanie, swoje powołanie...

Mówiąc o powołaniu, ma Ksiądz na myśli indywidualne powołanie życiowe człowieka czy coś więcej - jakąś zasadę życia?

Oczywiście chodzi o jedno i drugie, ale przez wiele lat pracowaliśmy z innymi moralistami, m. in. z ks. prof. Stanisławem Olejnikiem z Warszawy, ks. bp. Stanisławem Smoleńskim z Krakowa, ks. prof. Stanisławem Witkiem z Lublina, nad tym, żeby teologię moralną oprzeć na idei powołania. Różnica między nami polegała jednak na tym, że niektórzy z nich traktowali tę ideę zbyt szeroko, a przez to moim zdaniem bardziej płytko. Mnie zawsze chodziło o to, żeby idea powołania była rozumiana głęboko teologicznie jako powołanie od Boga i pod Jego kierownictwem. To przecież z idei powołania wynikają zobowiązania moralne. Ich spełnianie to właśnie konkretna ludzka odpowiedź na Boże wezwanie. Niektórzy chcieli z ideą powołania iść wszerz, tak pozytywistycznie, uwzględniając szeroko różne nauki szczegółowe, np. psychologię, socjologię, historię. A ja zawsze dążyłem do tego, żeby iść w głąb. Chociaż nauki empiryczne oczywiście szanuję i cenię.

Ja się po prostu upierałem przy idei powołania, odwołując się do Biblii. Przecież idea powołania to podstawowa nić łącząca biblijne wydarzenia, działanie wielkich biblijnych postaci, takich jak choćby: Mojżesz, Abraham, Apostołowie, święty Paweł. Przecież i słowa, i decyzje życiowe wielkich postaci Biblii to kroczenie za odczytaniem Bożego powołania. Aż dziw, że niektórzy tego nie rozumieli i nie chcieli przyjąć. To był moim zdaniem skutek jakiejś niechęci do jednolitej idei na korzyść modnego pluralizmu i kultu nauk szczegółowych.

Ta idea powołania jako podstawa i wiodaca idea teologii moralnej była też bliska ks. kard. Karolowi Wojtyle, z którym Ksiądz Profesor w Krakowie ściśle wspótpracowat.

Karol Wojtyła był dla mnie w moich poszukiwaniach podstaw teologii moralnej natchnieniem i mocnym wsparciem. Pamiętałem jego słowa skierowane 
kiedyś do mnie i uczestników pewnej konferencji naukowej w Krakowie: „trzeba iść drogą idei powołania”. To mnie inspirowało, tego się trzymałem. Powołanie integralne - obejmujące całego człowieka - jego ducha, psychikę, ciało, seksualność, podmiotowość. Z tego wynika zdrowe, chrześcijańskie spojrzenie na płciowość ludzką przed i w czasie małżeństwa.

Czy Ksiądz Profesor nie uważa, że takie pokusy pomniejszania teologii rodziny na korzyść innych nauk o rodzinie ciagle, $w$ różnej formie, powracaja?

Tak oczywiście, wracają wciąż na nowo. To dziwne, ale w nauce są nawroty różnych trendów. Pamiętasz, jak gorące były dyskusje w Instytucie Nauk o Rodzinie UKSW, gdy chodziło o zawartość treściową rodzącej się tzw. familiologii, którą niektórzy chcieli traktować jako tylko „liniowy” zestaw różnych nauk zajmujących się małżeństwem i rodziną, od biologii i ekonomii począwszy, poprzez psychologię, i socjologię, aż po filozofię i teologię? Wspierałem wtedy bardzo mocno ks. abpa Kazimierza Majdańskiego, walczącego na argumenty o właściwe, tzn. fundamentalne, miejsce teologii rodziny, jej powołania i wyznaczonych jej przez Boga zadań. Inaczej mówiąc, chodziło o to, żeby nauki o rodzinie miały własną strukturę i fundamenty. Nie można zbudować familiologii bez Boga na pierwszym miejscu. Bóg w osobie Jezusa Chrystusa przyjął los człowieka, los ludzkiej rodziny, stąd oczywiste, że - jak nas nauczał Jan Paweł II - bez Chrystusa nie można człowieka zrozumieć, człowiek sam siebie nie może zrozumieć. W tym też kontekście byłem zwolennikiem ej intronizacji Chrystusa Króla w sercach Polaków i polskich rodzinach. Oczywiście nie chodzi o to, żeby Chrystusa sadzać na tronie jak Piastów i Jagiellonów. Tu chodzi o wnętrze, o oddanie siebie Chrystusowi; każdy oddaje siebie, rodzice oddają swoje dzieci, biskupi i rządcy świeccy - naród, po to żeby były respektowane w polskim narodzie prawdy i wartości chrześcijańskie.

Księże Profesorze, Stolica Apostolska ustanowiła nowe święto Chrystusa Najwyższego i Wiecznego Kapłana. Będzie obchodzone w czwartek, tydzień przed uroczystością Bożego Ciała. W przyszłym roku wypadnie to, jak mi się wydaje, 23 maja.

Nie wiedziałem o tym nowym święcie. Cieszę się, będzie to dobre dla powołań i troski o świętość kapłanów. Trzeba jednak baczyć na to, żeby te dwa 
święta, te dwa tytuły chrystologiczne: Chrystus Król Wszechświata i Chrystus Najwyższy Kapłan, łączyć, spajać. Kapłan - i jego świętość - jest dla zbawiania świata, dla królowania Chrystusa w umysłach i sercach ludzi.

Ważnym polem działalności Księdza była publicystyka, zwłaszcza w sprawach obrony i promocji rodziny, a także obrony i promocji rodziny rodzin ojczyzny. Wiele osób, ja też do nich należałem, zaczynało czytanie „Naszego Dziennika" od artykulu czy felietonu ks. Bajdy.

Dziękuję Ci, że tak głośno się do tego przyznajesz, bo niektórzy uważali, że piszę zbyt jednoznacznie, gdy przestrzegam ewangelicznej zasady: tak - tak, nie - nie. Mówiono mi, raz nawet ktoś znaczący, że w życiu trzeba być giętkim, że się wtedy więcej zyska. Zapytałem - a co się zyska? Cisza. Dodałem: Warto, żeby to nie było coś, czego będzie się trzeba wstydzić. Dla mnie ojczyzna, naród to nie ustroje, partie, ale dziedzictwo pokoleń, którego nam nie wolno zmarnować, przetracić, zhańbić. Mamy je nienaruszone, a nawet ubogacone przekazać pokoleniu naszych potomków. Przecież mamy wszyscy w uszach wołanie naszego Rodaka: „Proszę was, abyście to duchowe dziedzictwo, któremu na imię Polska...”1 itd. To powinno zobowiązywać również wszystkich niewierzących i agnostyków, także liberałów. Dobro Polski, dobro narodu powinno być dla wszystkich dobrem wspólnym. Sprzeciwiałem się, mówiłem i pisałem w obronie polskich, patriotycznych wartości - historii, kultury, religii. Tak jak wołał Jan Paweł w 1980 roku w UNESCO w Paryżu: „Jestem synem narodu, który przetrwał najstraszniejsze doświadczenia dziejów i był przez sąsiadów skazywany na śmierć, ale przetrwał..."2 itd. Unia tak, pluralizm tak, ale oparte na wartościach chrześcijańskich, to znaczy boskich, Inaczej mamy gliniane nogi słonia.

W tym kontekście chciałbym jeszcze zapytać, czym dla Księdza jako człowieka i kapłana, i uczonego są słowa Bóg - Honor - Ojczyzna. Często się Ksiądz do tych słów odwolywał. Większość się tym chlubi, niektórzy się wyśmiewają.

1 Jan Paweł II, Homilia w czasie Mszy św. odprawianej na Błoniach (Kraków, 9 czerwca 1979 r.), w: Jan Paweł II, Dzieła zebrane, Kraków 2008, t. IX, s. 161.

2 Jan Paweł II, Przemówienie w siedzibie UNESCO W imię przyszłości kultury ( Paryż, 2 czerwca 1980 r.), w: Jan Paweł II, Dzieła zebrane, Kraków 2008, t. X, s. 104. 
Odpowiem krótko: dla mnie to nie są tylko słowa. To są narodowe symbole, świętości polskiego dziedzictwa, o którym tyle razy mówił nasz wielki Rodak, zwłaszcza w czasie pielgrzymek do Polski. Bóg - Honor - Ojczyzna, to moim zdaniem były przez historię i powinny być na przyszłość trzy filary, trzy najważniejsze wartości i dla świeckich, i dla duchownych, i również dla sprawujących władzę. Nikt nie powinien tych wartości lekceważyć czy też ignorować bo byłoby jak w opowieści o leśniku, co podrzynał gałąź, na której sam siedział. Gdybyśmy to odrzucili, to co będzie w zamian? Internacjonalizm, indywidualny egoizm, permisywizm? Panie, do kogóż pójdziemy....

Choć większość życia spędził Ksiądz Profesor w Warszawie, pracując na ATK, a potem UKSW, w Instytucie Studiów nad Rodzina, to jednak wrócit Ksiądz do swojej diecezji - tarnowskiej, $w$ której w latach 70-ych byt Ksiądz przez kilka lat ojcem duchownym $w$ seminarium i profesorem tzw. principiów teologii moralnej. Co by Ksiądz Profesor powiedział dzisiaj klerykom tarnowskiego seminarium?

Pewnie chciałbym powiedzieć tak: sięgajcie wyżej i wyżej. Przekraczanie siebie - uwarunkowań biologii organizmu i nacisków otoczenia - należy do istoty człowieczeństwa Wyżej, tzn. ponad to co widzisz i odczuwasz. Ja bym cały problem wychowania w ogóle, a szczególnie w seminarium, sprowadził do rozumienia tego, kim jest człowiek w całym swoim wyposażeniu, otrzymanym wprost od Boga i otoczenia, zwłaszcza od najbliższych w rodzinie. Do tego, że człowiek jest aż osobą - ze zdolnością do myślenia, wybierania, miłości, do kierowania się sumieniem, szukania i przylgnięcia do Boga. A więc osoba widziana nie jako jakaś indywidualna monada, ale w odniesieniu do drugiej osoby i osób Bożych. Osoba - do i dla innych, dla społeczeństwa, dla potrzebujących. Taki człowiek, taki ksiądz, taka osoba może nadawać kształt światu. Trzeba nam ciągle zdobywać siłę ducha. Sięgać wyżej to trudne, tak jak trudna jest wszelka metafizyka. Ale trzeba w tym kierunku starać się stale iść. Być człowiekiem, być Bożym człowiekiem - to pytanie i zadanie powinien mieć i każdy kleryk, i każdy ksiądz, również tak jak ja u kresu życia.

A co mam powiedzieć moim kolegom - ks. Michałowi i ks. Bolesławowi? $W$ czerwcu byliśmy tu w trójkę i Ksiądz Profesor obiecał wygtosić dla naszego 
rocznika, w czerwcu 2013 roku, rekolekcje. Miały być krótkie: kilka konferencji, modlitwa, spotkanie.

(Po chwili milczenia, przy zamkniętych oczach)

Gdy Wam obiecywałem, to było prawie pół roku temu, wiedziałem że źle się dzieje w moim organizmie, ale wtedy byłem jeszcze mocny. Dziś jest inaczej. Jak widzisz, leżę, trudno mi się poruszać, jestem słaby. Zostawmy to Panu Bogu, On wie. Ale chcę Wam coś powiedzieć. Musimy się wszyscy, i ja, i wy, modlić, żeby nas Pan Bóg pokrzepiał w tym, abyśmy ostatnie chwile naszego życia, dla jednych jeszcze odległe, dla innych tak jak dla mnie bliskie, mogli przeżywać jak najbliżej Niego i abyśmy jeszcze lepiej odczuwali, co to znaczy, że On do końca nas umiłował: nie do połowy, ale do końca. Módlmy się nawzajem za siebie. Obiecuję to i Was o to proszę.

(Po chwili milczenia) Polecam się Bogu i Maryi Bogarodzicy.

Ks. dr Władysław Szewczyk

Niech mi będzie wolno wypowiedzieć na koniec osobiste słowo o Księdzu Profesorze Jerzym. Ośmielę się powiedzieć tak: Ksiądz Jerzy łączył w swojej bogatej osobowości dwie wielkie postacie: św. Franciszka z Asyżu i św. Tomasza z Akwinu. Franciszek to abnegacja i asceza w odniesieniu do swoich potrzeb życia, pokora i prostota bycia w odniesieniu do innych oraz postawa służby - bycie dla, słowem, franciszkańskie „pokój i dobro”. Św. Tomasz z Akwinu to z kolei głębia i wnikliwość myślenia, nastawienie teocentryczne w teologii, idea wiodąca - powołanie przez Boga i naśladowanie Boga-Człowieka w Chrystusie. 